\title{
IbM Kelompok Tani Jamur Tiram di Kelurahan Tlogomulyo
}

\author{
Fatmasari Sukesti \\ fatmasaris@yahoo.com \\ Setia Iriyanto \\ setia seâyahoo.com \\ Nurhidajah Ana Hidayati \\ tekpang fikkesarahoo.co.id \\ Purnomo \\ purnomouniimus@y yahoo.co.id
}

Universitas Muhammadiyah Semarang

Riwayat Artikel: dikirim Oktober 2018, diterima September 2018, diterbitkan September 2018

Abstract

\begin{abstract}
Oyster mushrooms easily to cultivated so this activities become to choice of small and medium enterprises SMEs ) to conduct cultivation. Oyster mushroom (Pleurotus ostreatus) is a nutritious food ingredient with high protein, rich in vitamins and minerals, low in carbohydrates, fat and calories. Oyste mushroom products can not only be consumed in the form of cooked vegetables, but can be processed int a form processed foods like crispy mushrooms, mushroom chips, nuggets mushroom, mushroo dumplings, and other processed foods. Farmer groups " Agro Mandiri Graha" develop the cultivation oyster mushroom by processing into food products. With the IbM program the persons from Unimus tean partnered with farmer groups "Agro Mandiri Graha " to enhance the ability of members of the grotup the development of agribusiness and the strengthening of farmer groups became strong farmer: organizations and independent. The results obtained from $1 \mathrm{bM}$ are : improved the skills of farmers cultivat oyster mushrooms in oyster mushroom into food products like : mushroom chips, nuggets mushroom mushroom dumplings, meatballs mushrooms, mushroom satay and crispy mushrooms and improv financial management and marketing of products
\end{abstract}

Keywords : oyster mushrooms, processed foods, agribusiness development 


\section{PENDAHULUAN}

\section{Latar Belakang Masalah}

Indonesia sangat kaya akan hasil sayursayuran, buah, ikan,daging dan susu. Jamur merupakan salah satu jenis sayuran yang memiliki bentuk, warna sangat beragam dan rasa yang lezat jika dimasak. Sehingga minat masyarakat dalam mengkonsumsi jamur semakin hari semakin meningkat. Fenomena ini memberikan peluang usaha bagi masyarakat untuk membudidayakan jamur sebagai alternatif penambah penghasilan yang dapat meningkatkan taraf hidup ekonomi sekaligus menciptakan lapangan kerja baru bagi masyarakat.

Jamur Tiram mudah untuk dibudidayakan sehingga menjadi pilihan usaha kecil dan menengah untuk melakukan usaha budidaya ini. Jamur tiram (Pleurotus ostreatus) merupakan bahan makanan bernutrisi dengan kandungan protein tinggi, kaya vitamin dan mineral, rendah karbohidrat, lemak dan kalori. Jamur ini memiliki kandungan nutrisi seperti vitamin, fosfor, besi, kalsium, karbohidrat, dan protein. Untuk kandungan proteinnya, lumayan cukup tinggi, yaitu sekitar 10,5-30,4\%. Komposisi dan kandungan nutrisi setiap 100 gram jamur tiram adalah 367 kalori, 10,5-30,4 persen protein, 56,6 persen karbohidrat, 1,7-2,2 persen lemak, $0.20 \mathrm{mg}$ thiamin, $4.7-4.9 \mathrm{mg}$ riboflavin, $77,2 \mathrm{mg}$ niacin, dan $314.0 \mathrm{mg}$ kalsium. Kalori yang dikandung jamur ini adalah $100 \mathrm{kj} / 100$ gram dengan 72 persen lemak tak jenuh. Serat jamur sangat baik untuk pencernaan. Kandungan seratnya mencapai 7,4- 24,6 persen sehingga cocok untuk para pelaku diet. Berdasarkan penelitian Sunan Pongsamart, biochemistry, Faculty of Pharmaceutical Universitas Chulangkorn, jamur tiram mengandung protein, air, kalori, karbohidrat, dan sisanya berupa serat zat besi, kalsium, vitamin B1, vitamin B2, dan vitamin C.

Wilayah Semarang memungkinkan untuk melakukan budidaya jamur tiram. Didukung transportasi yang mudah membuat pendistribusian hasil panen jamur tiram juga mudah, sehingga menjadikan budidaya jamur tiram bisa untuk dikembangkan. Produk jamur tiram tidak hanya bisa dikonsumsi dalam bentuk sayuran dimasak, akan tetapi dapat diolah menjadi bentuk makanan olahan lain seperti jamur krispi, keripik jamur,nugget jamur, pepes jamur, sate jamur dan makanan olahan lain.
Kelompok budidaya jamur tiram yang tergabung dalam Kelompok Tani Jamur "Agro Graha Mandiri" yang beralamat di Jalan Wonomulyo Mukti Timur G III Rt 08 Rw 11, Perum Graha Mukti Utama Kelurahan Tlogomulyo, Kecamatan Pedurungan Semarang didirikan untuk mengatasi permasalahan ekonomi para anggotanya yang masih hidup dalam taraf kekurangan. Anggota dari kelompok usaha ini sebagian besar berprofesi sebagai pekerja serabutan dan pekerja tidak tetap. Dengan usaha baru ini diharapkan dapat meningkatkan taraf hidup dengan menambah penghasilan melalui usaha budidaya jamur tiram. Dan berkembangnya usaha ini akan dapat menciptakan lapangan kerja baru untuk masyarakat yang lain.

Kelompok Tani Jamur "Agro Graha mandiri" bergerak dalam bidang agribisnis usaha budidaya jamur tiram dengan menanam jamur tiram pada lahan di rumah anggota kelompok. Kelompok tani ini berjumlah 20 orang, dan telah membudidayakan jamur tiram sebanyak 500 sampai 1000 baglog bibit. Jamur dipanen setiap hari sebanyak 30 sampai $50 \mathrm{~kg}$ dan hasil panen dijual ke pengepul jamur. Tetapi karena jamur tiram basah tidak bertahan lama, kelompok tani ini juga mengembangkan usaha mengolah hasil panen jamur tiram menjadi makanan berupa keripik jamur, pepes jamur, nugget jamur dll makanan kering yang terbuat dari jamur tiram. Dengan usaha tersebut kelompok tani dapat meningkatkan kemampuan anggotanya dalam pengembangan agribisnis serta penguatan kelompok tani menjadi organisasi petani yang kuat dan mandiri.

\section{Target Luaran}

Program $\mathrm{I}_{\mathrm{b}} \mathrm{M}$ pada Kelompok Tani Jamur akan dilaksanakan ini akan menghasilkan: 1. Produk atau makanan yang berasal dari Jamur tiram berupa:
a. Jamur krispi
b. Keripik jamur
c. Pepes jamur
d. Nugget jamur
e. Siomay jamur
f. Sate jamur

2. Peningkatan jumlah produksi jamur tiram dan dengan peningkatan kualitas hasil produksi makanan olahan dan dapat memperoleh nomor ijin produksi rumah tangga.

3. Menerapkan manajemen keuangan/ pemasaran usaha jamur tiram

4. Sertifikat kegiatan Ipteks bagi masyarakat kelurahan Tlogomulyo dengan harapan hasil produksi bisa menjadi salah satu makanan oleh-oleh khas Semarang. 
Tujuan Pengabdian Masyarakat

Tujuan diadakannya kegiatan IbM ini adalah :

1. Meningkatkan ketrampilan kelompok tani jamur tiram mengolah jamur tiram menjadi produk makanan olahan

2. Meningkatkan kemampuan kelompok tani dalam meningkatkan mutu hasil produk.

3. Meningkatkan kemampuan manajemen keuangan, dan pemasaran hasil produksi

Manfaat Pengabdian Masyarakat

Adapun manfaat yang dapat diperoleh dari kegiatan IbM ini adalah:

I. Melaksanakan Tridarma Perguruan Tinggi dalam bidang pengabdian kepada masyarakat yaitu membantu program Pemerintah dalam pemberdayaan masyarakat guna mengatasi kemiskinan

2. Interaksi antara perguruan tinggi dan masyarakat secara langsung untuk membantu mengatasi permasalahan yang ada dalam masyarakat.

3. Mengembangkan usaha untuk meningkatkan ekonomi masyarakat dengan peran serta dosen, mahasiswa, lembaga penelitian dan pengabdian masyarakat, lembaga pemerintah dalam hal ini adalah dinas pertanian serta kelompok tani jamur tiram sebagai mitra kegiatan.

\section{METODE}

$$
\text { Kegiatan IbM dilakukan dengan }
$$
menggunakan metode

1. Penyuluhan/Ceramah

2. Pelatihan dan Pendampingan

3. Evaluasi
Kegiatan IbM dimulai dengan melaksanakan kegiatan penyuluhan peningkatan budidaya jamur tiram dengan bekerja sama dengan dinas terkait yaitu Dinas Pertanian Kota Semarang. Kemudian penyuluhan dilanjutkan dengan materi tentang pengembangan jamur tiram menjadi produk olahan makanan dari tim pengabdi dari Teknologi Pangan Unimus.

Kegiatan berikutnya adalah praktek pengolahan jamur tiram menjadi makanan olahan dengan mendatangkan 2 (dua) orang nara sumber produsen keripik jamur tiram dan produsen makanan nugget dan aneka makanan olahan dari jamur tiram. Kegiatan praktek berlangsung 2 (dua) kali yang dilakukan di laboratorium teknologi pangan Unimus, dan dilanjutkan praktek di tempat usaha kelompok tani.

Dalam kegiatan praktek pengolahan, tim pengabdi juga melakukan pendampingan selama kegiatan tersebut berlangsung. Selanjutnya pada bulan ke 3, kegiatan dilakukan evaluasi hasil proses praktek dan diberikan penyuluhan kembali tentang proses pengemasan, analisis usaha dan pemasaran. Selama kegiatan kelompok tani berkomunikasi secara intensif dengan tim pengabdi Unimus guna pencapaian hasil yang optimal.

Menjelang akhir kegiatan tim Unimus menyampaikan bantuan alat produksi berupa mesin oven, showcase dan sealler, serta bantuan bibit jamur tiram sebanyak 1.500 baglog, dengan harapan alat alat produksi bisa membantu mengembangkan usaha secara berkesinambungan. Kegiatan berakhir dengan pertemuan dengan kelompok tani dan mengevaluasi semua hasil yang telah dicapai.

Kegiatan IbM berakhir bulan Desember 2013, tetapi tim pengabdi Unimus tetap melaksanakan pemantauan dan pendampingan secara berkelanjutan agar pelaksanaan kegiatan pengabdian tidak berhenti pada program akan tetapi tetap berkomunikasi dan pembinaan terhadap kelompok UKM sebagai bagian integrasi akademik pada masyarakat dalam Tridarma Perguruan Tinggi darma pengabdian masyarakat. adalah

Adapun transfer ipteks yang dilakukan 


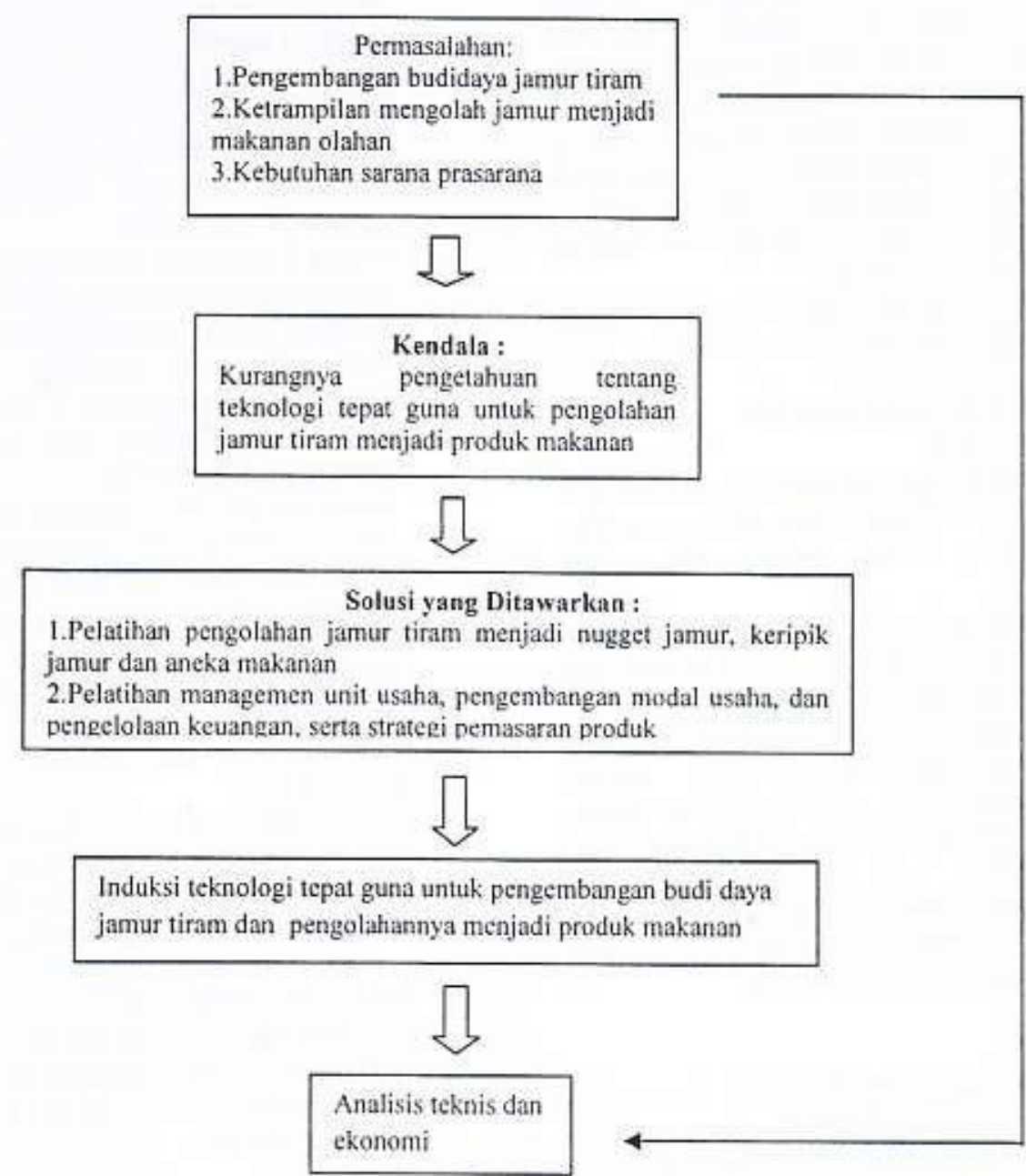

\section{HASIL DAN PEMBAHASAN}

Kegiatan IbM telah dilaksanakan mulai tanggal 7 Juli 2013, dengan pembukaan kegiatan di rumah salah satu anggota kelompok tani "Agro Graha Mandiri". Kegiatan berjalan dengan lancar dengan sambutan positif dari anggota kelompok tani. Kegiatan selanjutnya dilakukan dengan penyuluhan dan pelatihan pembuatan aneka produk makanan dari jamur tiram. Dalam pelaksanaan pengolahan produk makanan ini juga dilakukan pendampingan dan evaluasi hasil dari produk tersebut oleh tim pengabmas untuk menjamin hasil dari produk makanan tersebut.

Adapun hambatan selama kegiatan IbM berlangsung adalah sebagai berikut: Hambatan Kegiatan IbM adalah

a. Jenis kegiatan adalah pengolahan produk makanan, sehingga waktu pelaksanaan agak mundur dari jadwal dikarenakan bersamaan dengan bulan puasa dan libur hari raya Idul Fitri. b. Musim kemarau mempengaruhi terhadap produksi jamur tiram, sehingga pasokan bahan baku menjadi berkurang, menghambat kegiatan latihan praktek

c. Petani jamur tiram selain kegiatan bertani juga memiliki kegiatan/pekerjaan yang lain seperti menjadi guru, pedagang, sehingga kesulitan mengatur pertemuan atau kegiatan pelatihan bersama.

d. Karena kegiatan ini adalah merupakan proses awal dari pengolahan bahan jamur menjadi produk makanan maka hasil belum maksimal masih perlu banyak latihan dan pendampingan

e. Pendampingan terhadap hasil produk makanan olahan dan pemasaran hasil produksi Menyelesaikan Masalah:

a. Pembukaan pengabdian sudah dilaksanakan pada bulan Juli sebelum bulan puasa, dan kegiatan selanjutnya dikoordinasikan bersama setelah lebaran idul fitri.

b. Mengundang nara sumber dari produsen aneka makanan olahan untuk meningkatkan 
kreatifitas para petani jamur untuk bisa mengolah berbagai makanan dari jamur tiram.

c. Mengatur jadwal pertemuan/ kegiatan bersama di hari Minggu dan praktek pengolahan dilakukan di rumah masing masing anggota Tim pengabmas melakukan pendampingan.

d. Melakukan pendampingan kegiatan secara kontinu dan berkelanjutan sampai kelompok tani mampu melaksanakan proses produksi dengan baik, mulai dari pengolahan sampai pemasaran hasil produksi.

e. Dilakukan kegiatan berkelanjutan untuk pendampingan dan pemasaran produk

\section{KESIMPULAN DAN SARAN KESIMPULAN}

1. Kegiatan IbM dapat berjalan dengan baik dan lancar karena kerjasama yang baik antara Tim IbM, LPPM, Dinas terkait, dan mitra pengabmas

2. Antusias dan kerjasama dari mitra Kelompok Tani "Agro Graha Mandiri" sangat mendukung kelancaran kegiatan IbM

3. Hambatan bahan baku (jamur tiram) di musim kemarau diharapkan dapat diatasi dengan adanya penyuluhan tentang pemeliharaan budidaya jamur tiram di musim kemarau yang
lebih intensif

4. Petani memiliki motivasi dan keinginan serta kemauan untuk mengolah jamur tiram menjadi makanan olahan yang tahan lama.

\section{SARAN}

1. Jangka waktu pencairan dana $16 \mathrm{M}$ dan jangka waktu pelaksanaan kegiatan yang terlalu singkat 3 bulan) mohon dipertimbangkan untuk kualitas kegiatan pengabdian masyarakat.

2. Kegiatan pengabdian masyarakat tidak berhenti ketika program IbM selesai tapi dapat dilanjutkan berkesinambungan sebagai kegiatan rutin yang dilakukan LPPM terhadap yang mitra kerja binaan melalui kerjasama yang dibentuk sehingga memberikan penguatan terhadap pencitraan akademik di masyarakat.

\section{UCAPAN TERIMA KASIH}

Atas terlaksananya kegiatan IbM Kelompok Tani Jamur Tiram Kelurahan Tlogomulyo kami Tim Pengabmas pelaksana kegiatan mengucapkan terima kasih kepada:

1. Direktorat Penelitian dan Pengabdian kepada Masyarakat, Direktorat Jenderal Pendidikan Tinggi, Kemendiknas yang telah memberikan pendanaan kegiatan $\mathrm{TbM}$ sehingea dapat
berjalan dengan baik.

2. Rektor dengan baik.

Rektor Universitas Muhammadiyah Semarang yeng telah memberikan pembinaan kepada tim pengabdi pelaksana kegiatan IbM

3. Ketua dan staf Lembaga Penelitian dan Pengabdian Masyarakat Unimus yang telah memberikan fasilitas dan sarana prasarana pendukung kegiatan IbM

4. Ketua dan anggota kelompok tani -Agro Graha Mandiri" yang telah berkerja sama dengan sangat baik dengan seluruh tim pengabdi IbM schingga kegiatan dapat berjalan dengan lancar

5. Mahasiswa prodi Akuntansi semester VI Unimus yang telah membantu terlaksananya kegiatan IbM 6. Nara sumber dan seluruh Tim pengabdi
kegiatan $\mathrm{lbm}$

Semoga kegiatan IbM ini bisa bermanfast bagi masyarakat dan merupakan darma bakiti akademik dalam rangka membantu program pemerintah dalam pengentasan kemiskinan.

\section{DAFTAR PUSTAKA}

Cahyana, Muchroji dan Bakrum, 2009. Pembibitan, Pembudidayaan dan Analisis Usaha Budiday'a Jamur Tiram, Penebar Swadaya, Jakarta

http://

www.tanijogonegoro.com/2012/10 budidayajamur-tiram.html

Nurmalia, 2011, Nugget Jamur Tiram (Pleurotus ostreatus) Sebagai Alternatif Makanan Siap Saji Rendah Lemak dan Protein serta Tinggi Serat, Universitas Diponegoro,
Semarang Sinaga, 2003, Jamur Tiram dan Budidayanya, Penebar Swadaya, Jakarta

Yusianah, Mengolah Jamur Tiram Menjadi Camilan Bergizi dan Bernilai Jual, htrp:

//www.jamuren.wordpress.com/2012 pdf 